UDC 615.242:339.138

Yu. S. Maslit, O. A. Ruban, O. M. Ievtushenko

National University of Pharmacy

\title{
THE MARKETING SUBSTANTIATION OF THE RELEVANCE OF NEW DOMESTIC PRODUCTS DEVELOPMENT FOR TOPICAL APPLICATION IN DENTISTRY
}

Over the last few years, the market of dental services in our country is rapidly developing. Modern world technologies of dental disease treatment have influenced on the structure of the domestic pharmaceutical market - new drugs, new dosage forms have appeared, they are used not only in therapeutic dentistry, but also in periodontics, diseases of surgical profile, orthopaedic, aesthetic dentistry and orthodontics. Domestic manufacturers are always in an active innovative search, searching for new marketing opportunities.

Aim. To analyze the range of dental preparations for topical application at the pharmaceutical market of Ukraine in order to substantiate the relevance for creating new drugs in this field.

Materials and methods. The methods of content and marketing analysis were used; the studies were performed using the Compendium database and the State Register of Medicinal Products of Ukraine.

Results. The assortment of preparations for topical application in dentistry by dosage forms and composition has been analyzed. Dental gels with components of synthetic origin have been found to be in the lead. The comparative analysis of dental gels with other oral dosage forms has been conducted; the leading consumer benefits of this dosage form have been determined - good adhesion and high bioavailability. The structure of suppliers has been studied, and a high degree of import dependency has been found (73.3 \%).

Conclusions. The relevance of development and production of new domestic combined preparations for topical application in dentistry, in particular gels for the treatment and prevention of caries, inflammatory diseases of the periodontium, oral mucosa, as well as pathologies similar in aetiology arising from the use of dental prostheses of various designs.

Key words: dental diseases; medicines of topical application; pharmaceutical market; dental gels.

Ю. С. МАслІй, О. А. РУБАн, О. М. ЄВТУшЕнко

Національний фармацевтичний університет

МАРКЕТИНГОВЕ ОБГРУНТУВАННЯ ДОЦІЛЬНОСТІ РОЗРОБКИ НОВИХ ВІТЧИЗНЯНИХ ПРЕПАРАТІВ ДЛЯ МІСЦЕВОГО ЗАСТОСУВАННЯ У СТОМАТОЛОГІї

Останнім часом ринок стоматологічних послуг у нашій країні інтенсивно розвивається. Сучасні технології лікування стоматологічних захворювань у світі вплинули і на структуру вітчизняного фармацевтичного ринку: з'явилися нові ліки, нові лікарські форми, що застосовуються не тільки у терапевтичній стоматології, а й у пародонтології, при захворюваннях хірургічного профілю, в ортопедичній, естетичній стоматології та ортодонтії. Вітчизняні виробники завжди знаходяться в активному інноваційному пошуку, пошуку нових маркетингових можливостей.

Мета: аналіз асортименту стоматологічних препаратів для місцевого застосування на фармацевтичному ринку України для обгрунтування доцільності створення нових лікарських засобів у цій сфері.

Матеріали та методи: контент- та маркетингового аналізу; дослідження здійснювали з використанням бази даних Компендіуму та Державного реєстру лікарських засобів України.

Результати. Проаналізовано асортимент препаратів для місцевого застосування у стоматології за лікарськими формами та складом. Установлено, що провідні позиції займають стоматологічні гелі з компонентами синтетичного походження. Проведено порівняльний аналіз стоматологічних гелів з іншими оральними лікарськими формами, визначено головні споживчі переваги цієї лікарської форми - добра адгезійна здатність та висока біодоступність. Досліджено структуру постачальників та установлено високий ступінь імпортозалежності ринку (73,3%).

Висновки. Показано актуальність розробки і виробництва нових вітчизняних комбінованих препаратів для місцевого застосування у стоматології, зокрема гелів для лікування та профілактики карієсу, запальних захворювань пародонта, слизової оболонки порожнини рота, а також схожих за етіологією патологій, що виникають при користуванні зубними протезами різних конструкцій.

Ключові слова: стоматологічні захворювання; лікарські засоби місцевої дії; фармацевтичний ринок; стоматологічні гелі. 


\section{Ю. С. МАСЛИй, Е. А. РуБАН, Е. Н. ЕвТУШЕнко}

Национальный фармацевтический университет

\section{МАРКЕТИНГОВОЕ ОБОСНОВАНИЕ ЦЕЛЕСООБРАЗНОСТИ РАЗРАБОТКИ НОВЫХ ОТЕЧЕСТВЕННЫХ ПРЕПАРАТОВ ДЛЯ МЕСТНОГО ПРИМЕНЕНИЯ В СТОМАТОЛОГИИ}

В последнее время рынок стоматологических услуг в нашей стране интенсивно развивается. Современные технологии лечения стоматологических заболеваний в мире повлияли и на структуру отечественного фармацевтического рынка: появились новые лекарства, новые лекарственные формы, применяемые не только в терапевтической стоматологии, но и в пародонтологии, при заболеваниях хирургического профиля, в ортопедической, эстетической стоматологии и ортодонтии. Отечественные производители всегда находятся в активном инновационном поиске, поиске новых маркетинговых возможностей.

Цель: анализ ассортимента стоматологических препаратов для местного применения на фармацевтическом рынке Украины для обоснования целесообразности создания новых лекарственных средств в этой сфере.

Материалы и методы: контент- и маркетингового анализа; исследования проводили с использованием базы данных Компендиума и Государственного реестра лекарственных средств Украины.

Результаты. Проанализирован ассортимент препаратов для местного применения в стоматологии по лекарственным формам и составам. Установлено, что лидирующие позиции занимают стоматологические гели с компонентами синтетического происхождения. Проведен сравнительный анализ стоматологических гелей с другими оральными лекарственными формами, определены главные потребительские преимущества данной лекарственной формы - хорошая адгезионная способность и высокая биодоступность. Исследована структура поставщиков и установлена высокая степень импортозависимости рынка (73,3%).

Выводы. Показана актуальность разработки и производства новых отечественных комбинированных препаратов для местного применения в стоматологии, в частности гелей для лечения и профилактики кариеса, воспалительных заболеваний пародонта, слизистой оболочки полости рта, а также похожих по этиологии патологий, возникающих при пользовании зубных протезов различных конструкций.

Ключевые слова: стоматологические заболевания; лекарственные средства местного действия; фармацевтический рынок; стоматологические гели.

Statement of the problem. Dental diseases remain one of the most widespread problems worldwide due to their steady growth and progressive courses among different age groups of patients [1].

It is known that dental diseases have a negative impact on the human body and lead to various complications not only local, but also systemic in nature [2]. To date, caries has the leading place among diseases of the hard tissues of teeth, while among the pathologies of the soft tissues of the oral cavity there are infectious-inflammatory diseases of the periodontium (gingivitis, periodontitis) and the mucous membrane (stomatitis). Thus, according to medical statistics, caries occurs in more than $80 \%$ of adolescents and more than $90 \%$ of adults; only $8-12 \%$ of the population have a healthy periodontium, $53 \%$ have the initial inflammatory phenomena, $23 \%$ have the initial destructive changes, and $12 \%$ have moderate and severe lesions [1, 3-5]. In addition, professionals note that the level of dental morbidity among children, especially at an early age, has recently significantly increased. Most often, children seek for specialized medical aid in connection with lesions of the hard tissues of teeth (50-80\%), the periodontial tissues and the mucous membrane of the oral cavity $(40-60 \%)[3,6]$.

These pathologies are common causes of the tooth loss, resulting in the need for partial or complete prosthetics [7]. According to the scientific literature, the use of dentures is one of the most common causes of inflammatory reactions, leading to the appearance of hypersensitivity and bleeding gums, and in the long course to the development of serious chronic diseases. In this case, inflammatory processes can manifest themselves as gingivitis, periodontitis, stomatitis, pressure ulcers and chronic trauma [8-10].

However, in modern dental practice one of the main places is occupied by the local treatment of oral cavity diseases $[1,5,11,12]$.

In view of the above, providing the population with effective dental drugs for topical application requires sufficient information on their range and development opportunities for the pharmaceutical market. In this regard, there is a need for marketing research of the domestic market of drugs of this group.

Analysis of recent research and publications. The domestic pharmaceutical market 


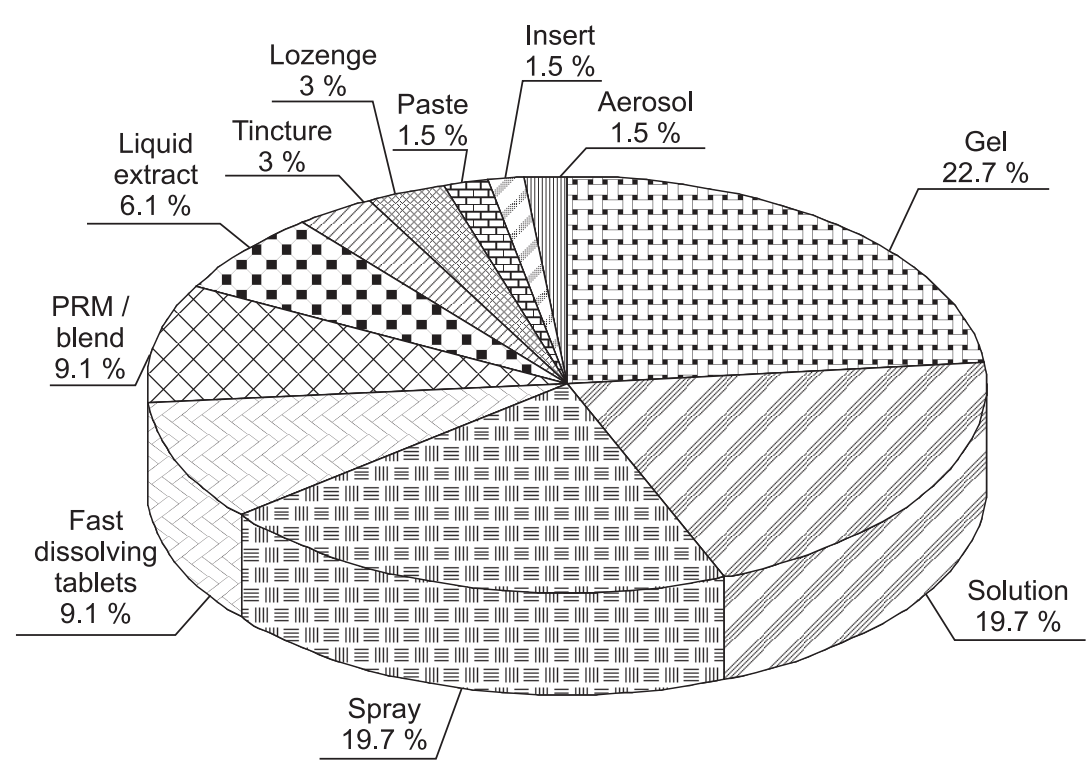

Fig. Distribution of dental drugs for topical application by dosage forms

of dental drugs in different periods was studied in the works of L. L. Davtyan, O. F. Piminov, T. G. Yarnyh, L. I. Shulga, N. V. Khokhlenkova, T. P. Zarichna, G. R. Kozyr, Y. M. Kobets et al. [13-15].

Identification of aspects of the problem unsolved previously. However, despite the attention of the scientific community to the problem, publications on the feasibility of creating dental products for topical application are fragmentary. In particular, there is no detailed analysis of compositions (the structure of API) of dental drugs for topical application and their pharmacological action, as well as a limited number of studies of dental drugs to eliminate pathologies that arise during adaptation to prostheses.

Objective statement of the article. The aim of the work was to analyze the range of dental preparations for topical application at the pharmaceutical market of Ukraine in order to substantiate the relevance for creating new drugs in this field.

Materials and methods. The methods of content and marketing analysis were used in the work. The studies were conducted using the Compendium database [16] and the State Register of Medicinal Products of Ukraine [17].

Presentation of the main material of the research. According to the ATC-classification, there is group A01A - "Stomatological preparations", which, in turn, is divided into subgroups: A01A B - "Anti-infectives and antiseptics for local oral treatment" and A01A D - "Other agents for local oral treatment" [16]. The study of the range of dental drugs at the domestic market has shown that as of early 2019, the study group has about 60 drugs for all dosage forms, among them gels, solutions and sprays are the most common (Fig.).

According to the prescribing information, dental preparations contain chemical, biogenic, herbal components and combinations thereof $[16,17]$.The list of possible combinations is rather wide. The characteristics of active pharmaceutical ingredients (API) in the composition of the drugs under research (the number of references to these substances in the composition of drugs and their pharmacological action) are given in Tab. 1.

According to the results of the analysis of the dental drug composition (Tab. 1), chlorhexidine gluconate, metronidazole benzoate and benzidamine hydrochloride with the antibacterial, anti-inflammatory, antiseptic and analgesic action take the leading positions among substances of synthetic origin; among products of natural origin there are API based on chamomile and sage with the astringent, anti-inflammatory, antimicrobial, antiseptic, disinfectant, hemostatic and analgesic activity. It has been found that among drugs containing components of natural origin the combined drugs prevail, their pharmacological action is provided not by one species, but by a complex of the plant raw material (PRM) ("Phytodent", 


\section{API IN THE COMPOSITION OF DENTAL DRUGS THAT ARE AVAILABLE AT THE PHARMACEUTICAL MARKET OF UKRAINE}

\begin{tabular}{|c|c|c|}
\hline The name of the API & $\begin{array}{l}\text { Number } \\
\text { of references } \\
\text { in the } \\
\text { composition } \\
\text { of drugs }\end{array}$ & Pharmacotherapeutic action \\
\hline 1 & 2 & 3 \\
\hline \multicolumn{3}{|c|}{ API of synthetic origin } \\
\hline Chlorhexidine gluconate & 10 & Antimicrobial, antiseptic \\
\hline Metronidazole benzoate & 8 & Anti-protozoal, antibacterial \\
\hline Benzidamine hydrochloride & 8 & Anti-inflammatory, analgesic, antiseptic \\
\hline Lidocaine hydrochloride & 4 & Anesthetic \\
\hline Hexetidine & 4 & $\begin{array}{l}\text { Antifungal, antiseptic, topical hemostatic, analgesic, } \\
\text { coating and deodorizing }\end{array}$ \\
\hline Choline salicylate & 3 & Anesthetic, anti-inflammatory \\
\hline Cetalkonium chloride & 2 & Antimicrobial, antifungal \\
\hline $\begin{array}{l}\text { Polidocanol } 600 \text { (macrogol } \\
\text { lauryl ether) }\end{array}$ & 2 & Local anesthetic \\
\hline Camphor (racemic) & 2 & Antiseptic, analgesic and anti-inflammatory \\
\hline Clotrimazole & 1 & \multirow{2}{*}{ Antibacterial, antifungal, antiprotozoal } \\
\hline Miconazole nitrate & 1 & \\
\hline Benzocaine & 1 & Anesthetic \\
\hline Thymol & 1 & Antiseptic \\
\hline Salicylic acid & 1 & Antimicrobial, antiseptic \\
\hline Sodium fluoride & 1 & Remineralizing, bactericidal, caries prophylactic \\
\hline Hydrochloride & 1 & Antiseptic \\
\hline Diclofenac sodium & 1 & Analgesic, antipyretic, anti-inflammatory \\
\hline \multicolumn{3}{|c|}{ API of natural origin } \\
\hline Matricaria chamomilla & 10 & $\begin{array}{l}\text { Painkiller, anti-inflammatory, antiseptic, hemostatic, } \\
\text { astringent, disinfectant }\end{array}$ \\
\hline Salvia officinalis & 7 & $\begin{array}{l}\text { Astringent, anti-inflammatory, antiseptic, disinfectant, } \\
\text { hemostatic, antimicrobial }\end{array}$ \\
\hline Propolis & 4 & $\begin{array}{l}\text { Bactericidal, analgesic, antiseptic, anti-inflammatory, } \\
\text { reparative }\end{array}$ \\
\hline Acorus calamus & 4 & $\begin{array}{l}\text { Antiseptic, antibacterial, analgesic, anti-inflammatory, } \\
\text { disinfectant }\end{array}$ \\
\hline Mentha piperita & 4 & Antiseptic, antibacterial, analgesic, antifungal \\
\hline Eucalyptus viminalis & 3 & $\begin{array}{l}\text { Antimicrobial, analgesic, antiseptic, disinfectant, im- } \\
\text { munomodulating }\end{array}$ \\
\hline Quercus robur & 3 & Astringent, anti-inflammatory \\
\hline Calendula officinalis & 3 & Anti-inflammatory, bactericidal, wound healing \\
\hline Thymus serpyllum & 3 & Anti-inflammatory, antimicrobial \\
\hline Achillea millefolium & 2 & Hemostatic, anti-inflammatory, bactericidal \\
\hline Arnica montana & 2 & Hemostatic, astringent, analgesic \\
\hline Symphytum officinale & 2 & Anesthetic, anti-inflammatory, hemostatic, reparative \\
\hline Capsicum & 1 & $\begin{array}{l}\text { Antiseptic, refreshing, locally irritating, distracting, } \\
\text { moderate antibacterial }\end{array}$ \\
\hline Hypericum perforatum & 1 & Astringent, anti-inflammatory, antimicrobial, reparative \\
\hline Urtica dioica & 1 & $\begin{array}{l}\text { Wound healing, hemostatic, anti-inflammatory, } \\
\text { antiseptic }\end{array}$ \\
\hline Styphnolobium japonicum & 1 & Bactericidal, anti-inflammatory, analgesic \\
\hline
\end{tabular}


Continuation of Table 1

\begin{tabular}{|l|l|l|}
\hline \multicolumn{1}{|c|}{1} & 2 & \multicolumn{1}{c|}{3} \\
\hline Chelidonium majus & 1 & Anti-inflammatory, analgesic \\
\hline Rosa canina & 1 & Anti-inflammatory, immunostimulating \\
\hline Piper nigrum & 1 & Antimicrobial, locally irritating \\
\hline Artemisia absinthium & 1 & Antimicrobial \\
\hline Satureja hortensis & 1 & Astringent, bactericidal, antispasmodic \\
\hline Dianthus deltoides & 1 & Antiseptic, analgesic \\
\hline Zingiber officinale & 1 & Anti-inflammatory \\
\hline Althaea officinalis & 1 & Anti-inflammatory, enveloping, reparative \\
\hline Melilotus officinalis & 1 & Anti-inflammatory, analgesic, antibacterial \\
\hline Rheum rhaponticum & 1 & $\begin{array}{l}\text { Anti-inflammatory, astringent, prevents tartar forma- } \\
\text { tion }\end{array}$ \\
\hline Sanguisorba officinalis & 1 & $\begin{array}{l}\text { Anti-inflammatory, hemostatic, analgesic, astringent, } \\
\text { antiseptic }\end{array}$ \\
\hline Sambucus nigra & 1 & Anti-inflammatory, analgesic \\
\hline $\begin{array}{l}\text { Deproteinized hemoderivate } \\
\text { of calf blood }\end{array}$ & 1 & $\begin{array}{l}\text { Protects tissues in hypoxia and nutritional deficiency, } \\
\text { promotes tissue regeneration, accelerates and im- } \\
\text { proves wound healing }\end{array}$ \\
\hline Salt of Pomorie Lake & 1 & Anti-inflammatory, reparative, weak analgesic \\
\hline
\end{tabular}

"Rotokan", "Stomatophyt", "Stomatophyt A", "Phytokan-GNCLS", "Stomat-phyto", "Maraslavin", "Anginophyt").

As can be seen from the analysis of the market, gels take the predominant position among various dosage forms; it is due to the effectiveness of their action and ease of use in the oral cavity [18-20]. Taking into account the data of scientific publications and the composition of the group of drugs studied [12,16-23] a comparative characterization of the physicochemical and technological properties of dental gels with other oral dosage forms under research was conducted to determine their advantages and disadvantages (Tab. 2).

As shown by the comparative analysis (Tab. 2), gels are characterized by good consumer properties and high bioavailability due to ease of use, localization of action, high adhesive ability and prolonged retention on the surface of

Table 2

\section{A COMPARATIVE CHARACTERISTIC OF DENTAL GELS AGAINST OTHER ORAL DOSAGE FORMS}

\begin{tabular}{|c|c|c|c|c|c|c|c|}
\hline \multirow[b]{2}{*}{ Properties } & \multicolumn{7}{|c|}{ The presence of definite properties in the dosage form studied } \\
\hline & gel & $\begin{array}{c}\text { spray, } \\
\text { aerosol }\end{array}$ & $\begin{array}{l}\text { solution, } \\
\text { tincture, } \\
\text { liquid } \\
\text { extract }\end{array}$ & $\begin{array}{c}\text { fast } \\
\text { dissolving } \\
\text { tablet, } \\
\text { lozenges }\end{array}$ & $\begin{array}{l}\text { PRM, } \\
\text { blends }\end{array}$ & $\begin{array}{c}\text { oromucosal } \\
\text { paste }\end{array}$ & $\begin{array}{l}\text { dental } \\
\text { inserts }\end{array}$ \\
\hline Adhesive ability & + & $+^{*}$ & - & - & - & $t^{*}$ & + \\
\hline $\begin{array}{l}\text { Prolongation of the } \\
\text { effect (prolonged } \\
\text { retention on the } \\
\text { surface of the oral } \\
\text { cavity tissues) }\end{array}$ & + & $+^{*}$ & - & - & - & $+^{*}$ & + \\
\hline $\begin{array}{l}\text { Localization of the } \\
\text { action }\end{array}$ & + & + & - & - & - & + & + \\
\hline $\begin{array}{l}\text { Possibility of taking } \\
\text { medicines on an } \\
\text { outpatient basis }\end{array}$ & + & + & + & + & + & + & - \\
\hline Ready-to-use form & + & + & + & + & - & + & + \\
\hline Easy of transporting & + & - & - & + & + & + & + \\
\hline
\end{tabular}

Note. $+^{*}$ - property is available, but weaker than in gels. 
the oral cavity tissues [12, 18-23], which are the leading factors for application in dental practice. In addition, in inflammatory periodontal diseases, the oral mucosa is inflamed and sensitive to coarse food and drugs; therefore, the use of a semisolid dosage form is optimal in the treatment of such pathologies. Thus, despite the sufficiently wide range of topical dental preparations, all drugs should be prescribed only in the rational dosage forms, in which they maximize their therapeutic effect and minimize the possible side effects [24].

In Tab. 3 the structure of API and indications for use in dental gel formulations available at the pharmaceutical market and permitted for sale in Ukraine are summarized.

According to the results obtained (Tab. 3), there are 15 dental gels at the pharmaceutical market of Ukraine, of them only one is monopreparation, the rest are combined drugs.

Table 3

\section{THE STUDY OF THE COMPOSITION AND INDICATIONS FOR USE OF DENTAL GELS PRESENT AT THE PHARMACEUTICAL MARKET OF UKRAINE}

\begin{tabular}{|c|c|c|c|c|}
\hline API & $\begin{array}{c}\text { The name of } \\
\text { the drug }\end{array}$ & Manufacturer & $\begin{array}{c}\text { Pharmacotherapeutic } \\
\text { group }\end{array}$ & Indications \\
\hline 1 & 2 & 3 & 4 & 5 \\
\hline \multirow{7}{*}{$\begin{array}{l}\text { Metronidazole } \\
\text { benzoate, } \\
\text { chlorhexidine } \\
\text { gluconate }\end{array}$} & $\begin{array}{l}\text { Metroviol } \\
\text { denta }\end{array}$ & $\begin{array}{l}\text { PJSC PF "Viola", } \\
\text { Ukraine }\end{array}$ & Antiseptic drugs & \multirow{7}{*}{$\begin{array}{l}\text { Infectious-inflammatory } \\
\text { diseases of the peri- } \\
\text { odontium and the oral } \\
\text { mucosa; toothache of } \\
\text { infectious origin }\end{array}$} \\
\hline & $\begin{array}{l}\text { Stomato-gel } \\
\text { Zdorovia }\end{array}$ & $\begin{array}{l}\text { PC Zdorovia LLC, } \\
\text { Ukraine }\end{array}$ & \multirow{3}{*}{$\begin{array}{l}\text { Antimicrobial and anti- } \\
\text { septic agents for topical } \\
\text { application in dentistry }\end{array}$} & \\
\hline & $\begin{array}{l}\text { Metronidazole } \\
\text { denta }\end{array}$ & $\begin{array}{l}\text { Arpimed Ltd., Re- } \\
\text { public of Armenia }\end{array}$ & & \\
\hline & Metrohex & $\begin{array}{l}\text { Group Pharmaceuti- } \\
\text { cals Ltd., India }\end{array}$ & & \\
\hline & $\begin{array}{l}\text { Metrogyl } \\
\text { Denta }^{\circ}\end{array}$ & $\begin{array}{l}\text { Unique Pharmaceu- } \\
\text { tical Laboratories, } \\
\text { India }\end{array}$ & \multirow[t]{3}{*}{$\begin{array}{l}\text { Preparations for the } \\
\text { treatment of protozoal } \\
\text { infections }\end{array}$} & \\
\hline & Dentagel $^{\circ}$ & $\begin{array}{l}\text { PJSC "Fitofarm", } \\
\text { Ukraine }\end{array}$ & & \\
\hline & Metrodent $^{\circ}$ & $\begin{array}{l}\text { Encube Ethicals Pri- } \\
\text { vate Limited, India }\end{array}$ & & \\
\hline $\begin{array}{l}\text { Metronidazole } \\
\text { benzoate }\end{array}$ & $\begin{array}{l}\text { Metrozole } \\
\text { denta }\end{array}$ & $\begin{array}{l}\text { Genom Biotech PVT. } \\
\text { Ltd., India }\end{array}$ & $\begin{array}{l}\text { Antimicrobial and anti- } \\
\text { septic agents for topical } \\
\text { application in dentistry }\end{array}$ & $\begin{array}{l}\text { Oral inflammatory di- } \\
\text { seases caused by pa- } \\
\text { thogens, sensitive to } \\
\text { metronidazole }\end{array}$ \\
\hline $\begin{array}{l}\text { Diclofenac } \\
\text { sodium, } \\
\text { chlorhexidine } \\
\text { gluconate }\end{array}$ & Dicloran denta & $\begin{array}{l}\text { Unique Pharmaceu- } \\
\text { tical Laboratories, } \\
\text { India }\end{array}$ & $\begin{array}{l}\text { Antimicrobial and anti- } \\
\text { septic agents for topical } \\
\text { application in dentistry }\end{array}$ & $\begin{array}{l}\text { Infectious-inflammatory } \\
\text { diseases of the oral } \\
\text { cavity in adults and chil- } \\
\text { dren over the age of 15; } \\
\text { toothache; condition } \\
\text { after tooth extraction }\end{array}$ \\
\hline \multirow{2}{*}{$\begin{array}{l}\text { Choline salicy- } \\
\text { late, cetalko- } \\
\text { nium chloride }\end{array}$} & Cholisal & $\begin{array}{l}\text { Jelfa AT Pharm Fac- } \\
\text { tory, Poland }\end{array}$ & Antiseptic drugs & \multirow{2}{*}{$\begin{array}{l}\text { Inflammatory, ulcera- } \\
\text { tive-necrotic, infectious } \\
\text { and trophic lesions of } \\
\text { the oral mucosa; use of } \\
\text { dentures; minor surgery }\end{array}$} \\
\hline & Cholicet & $\begin{array}{l}\text { Genom Biotech PVT. } \\
\text { Ltd., India }\end{array}$ & $\begin{array}{l}\text { Agents for topical ap- } \\
\text { plication in dentistry }\end{array}$ & \\
\hline \multirow{2}{*}{$\begin{array}{l}\text { Chamomile } \\
\text { flowers tinc- } \\
\text { ture, lidocaine } \\
\text { hydrochloride, } \\
\text { thymol }\end{array}$} & Kamistad & $\begin{array}{l}\text { Stada Artznimittel } \\
\text { AG, Germany }\end{array}$ & \multirow[t]{2}{*}{ Topical anesthetics } & \multirow{2}{*}{$\begin{array}{l}\text { Treatment of lesions of } \\
\text { gums and the mucous } \\
\text { membrane of the oral } \\
\text { cavity; use of dentures; } \\
\text { prevention of pain and } \\
\text { discomfort caused by } \\
\text { teething and orthodon- } \\
\text { tic procedures }\end{array}$} \\
\hline & $\begin{array}{l}\text { Camident- } \\
\text { Zdorovia }\end{array}$ & $\begin{array}{l}\text { PC Zdorovia LLC, } \\
\text { Ukraine }\end{array}$ & & \\
\hline
\end{tabular}


Continuation of Table 3

\begin{tabular}{|l|l|l|l|l|}
\hline 1 & \multicolumn{1}{|c|}{2} & \multicolumn{1}{c|}{3} & \multicolumn{1}{c|}{4} & \multicolumn{1}{c|}{5} \\
\hline $\begin{array}{l}\text { Chamomile } \\
\text { flowers ex- } \\
\text { tract, lidocaine } \\
\text { hydrochloride }\end{array}$ & $\begin{array}{l}\text { Kamistad- } \\
\text { gel N }\end{array}$ & $\begin{array}{l}\text { Stada Artzneimittel } \\
\text { AG, Germany }\end{array}$ & $\begin{array}{l}\text { Agents for the local ap- } \\
\text { plication in dentistry }\end{array}$ & $\begin{array}{l}\text { Treatment of mild in- } \\
\text { flammatory lesions } \\
\text { of gums and the mu- } \\
\text { cous membrane of the } \\
\text { oral cavity }\end{array}$ \\
\hline $\begin{array}{l}\text { Chamomile } \\
\text { tincture, lido- } \\
\begin{array}{l}\text { caine hydro- } \\
\text { chloride, poly- } \\
\text { docanol 600 }\end{array}\end{array}$ & $\begin{array}{l}\text { Dentinox- } \\
\text { gel N }\end{array}$ & $\begin{array}{l}\text { Dentinox Ge- } \\
\text { sellschaft fur } \\
\text { pharmazeutische } \\
\text { Praparate Lenk \& } \\
\text { Schuppan, Germany }\end{array}$ & $\begin{array}{l}\text { Products for application } \\
\text { in dentistry }\end{array}$ & $\begin{array}{l}\text { To facilitate teething of } \\
\text { the primary teeth (irrita- } \\
\text { tion of gums, inflamma- } \\
\text { tion and pain) }\end{array}$ \\
\hline
\end{tabular}

Chamomile is used as a component of natural origin in dental gels in the form of tincture and extract, and as a local anesthetic, lidocaine hydrochloride. In addition, only 4 gels (including 1 domestic drug Kamident-Zdorovie, "PC Zdorovie" LLC) in indications for use have a recommendation for the treatment of pathologies or injuries of the mucous membrane caused by the use of a denture, which is very relevant today, taking into the prevalence of this procedure among patients of different age groups [7-10].

Based on the analysis of dental gel manufacturers it has been found that the market is import-dependent (73.3 \%). Thus, by the number of drugs on offer India takes the first place (6), followed by Ukraine (4), Germany (3) and Poland and Armenia (1). However, according to the results of the analysis, domestic dental gels, unfortunately, do not have the original composition, and are often generic drugs of foreign production.

These dental gels according to the ATC-classification belong to the groups A01A B67** "Metronidazole, combinations" (53.3\%) and A01A D11 "Others" (46.7 \%) and are most often used in cases of infectious inflammatory diseases of the periodontium and the mucous membrane of the oral cavity. It should be noted that at the market there are absolutely no preparations in the form of gels for the prevention of caries (A01A A). The insufficient number of domestic products for use in the adaptation period during prosthetics at the pharmaceutical market is also a pressing issue. Considering etiopathogenesis of periodontal diseases and symptoms that occur when patients adapt to prostheses it is necessary to provide a medicinal product with the polyvalent action, namely the antimicrobial, anti-inflammatory, analgesic, hemostatic and reparative action. The main issue in the development of new dental gels is the choice of an antimicrobial agent that would protect against bacteria, without disrupting the normal flora of the oral cavity, contribute to the enhancement of the protective properties of saliva and strengthen the local immunity. However, according to the analysis of drugs in the form of dental gels, in group A01A B "Antimicrobial and antiseptic preparations for topical application in dentistry" only synthetic metronidazole-containing preparations are available.

Therefore, the data analyzed indicate the relevance of creating competitive domestic combined dental preparations for topical application, in particular gels, which would have a multivector effect and increase the effectiveness of pharmacotherapy of caries, infectious-inflammatory diseases of the periodontium and mucous membrane of the oral cavity, as well as prostheses-related pathologies, i.e. had a complex effect on both hard and soft tissues of the oral cavity.

\section{Conclusions}

1. The assortment of preparations for topical application in dentistry by dosage forms and composition has been analyzed. Dental gels (22.7\%), solutions and sprays (19.7\% each) mainly containing API of synthetic origin were found to be in the lead.

2 . The comparative analysis of dental dosage forms for topical application has determined a significant advantage of gels in their consumer characteristics.

3 . The composition of the manufacturing companies has been analyzed; the API structure and indications for use in dental gel form have been summarized. There is a high degree of import dependence of the market (73.3\%); 
thus, among dental gels of domestic production there are only 4 products having the composition similar with gels of foreign production: Kamident-Zdorovia (Ukraine) - Kamistad (Germany); Metroviol Denta, Stomato-Gel Zdorovia and Dentagel (Ukraine) - Metronidazole Denta (Republic of Armenia), Metrohex, Metrogyl Denta and Metrodent (India).

4. The marketing research conducted has found a limited number of domestic dental gels at the pharmaceutical market of Ukraine. Due to the problem of the early loss of teeth and prosthetics, only 1 gel of the Ukrainian production is recommended for the treatment of pathologies or injuries of the mucous membrane caused by the use of dentures. In addition, there are no gel formulations available to prevent caries, which is a precursor to many oral diseases and one of the common causes of the tooth loss.

5 . Therefore, a relevant direction of the pharmaceutical technology today is the search for effective API that would have a complex effect on the hard and soft tissues of the oral cavity, and development of new quality, competitive and affordable domestic drugs in the form of dental gels.

Conflict of interests: authors have no conflict of interests to declare.

\section{References}

1. Стоматологічні захворювання: терапевтична стоматологія : підручник (BНЗ I-III р. а.) / А. В. Борисенко, М. Ю. Антоненко, Л. В. Линовицька та ін. ; за ред. А. В. Борисенка. - К. : Медицина, 2017. - 664 c.

2. Борисенко, А. В. Вплив захворювань пародонту на загальний стан організму / А. В. Борисенко // Здоров'я суспільства. - 2013. - № 1. - С. 32-37.

3. Мельник, В. С. Аналіз поширеності захворювань зубощелепної системи, які формують попит на стоматологічні послуги / В. С. Мельник, М. Е. Ізай, Я. І. Дуганчик // Молодий вчений. - 2016. - № 12.1 (40). - С. 166-169.

4. Костригина, Е. Д. Современный взгляд на этиопатогенез пародонтита (обзор литературы) / Е. Д. Костригина, Л. А. Зюлькина, П. В. Иванов // Известия высших учебных заведений. Поволжский регион. Медицинские науки. - 2017. - № 3 (43). - С. 118-128.

5. Пародонтология : нац. рук-во / под ред. Л. А. Дмитриева. - М. : ГЭОТАР-Медиа, 2014. - 704 с.

6. Частота стоматологічних захворювань у дітей / Е. Н. Дичко, І. В. Ковач, Ю. В. Хотімська, Н. В. Федоряк // Медичні перспективи. - 2012. - Т. 17, № 2. - С. 114-116.

7. Сучасні погляди на проблематику передчасної втрати зубів / С. Б. Герасименко, А. К. Семенова, Г. А. Єрошенко, Н. В. Гасюк // Вісник проблем біології і медицини. - 2016. - Вип. 2, т. 1 (128). C. 174-178.

8. Альманах з ортопедичної стоматології : навч. посібник / П. А. Гасюк, Є. Я. Костенко, В. Р. Мачоган, С. О. Росоловська, А. Б. Воробець. - Тернопіль : Навчальна книга - Богдан, 2016. - 352 с.

9. Трезубов, В. Н. Ортопедическая стоматология. Пропедевтика и основы частного курса / В. Н. Трезубов, А. С. Щербаков, Л. М. Мишнев. - С.Пб. : Спецлит, 2011. - 408 с.

10. Соколовська, В. М. Вплив акрилових пластмас на слизову оболонку порожнини рота / В. М. Соколовська, М. Я. Нідзельський, М. О. Дудченко // Дерматовенерология. Косметология. Сексопатология. - 2015. - № 3-4. - С. 212-215.

11. Шманько, В. В. Сучасні підходи до лікування хвороб пародонта і слизової оболонки порожнини рота / В. В. Шманько, М. І. Котик, М. В. Микитів // Вісник наукових досліджень. - 2015. - № 4. - С. 71-74.

12. Орехова, Л. Ю. Системы локальной доставки лекарственных препаратов в пародонтологии / Л. Ю. Орехова, Т. В. Кудрявцева, Ю. С. Бурлакова // Пародонтология. - 2016. - № 1. - С. 34-39.

13. Динаміка розвитку ринку стоматологічних лікарських засобів України / Л. Л. Давтян, А. С. Воронкіна, Д. В. Рева, О. С. Куколевська // Фармацевтичний журнал. - 2015. - № 6. - С. 10-18.

14. Дослідження асортименту лікарських засобів для місцевого застосування в стоматології / Г. Р. Козир, М. М. Васенда, І. Р. Міц, Р. Л. Козир // Фармацевтичний часопис. - 2018. - № 1. C. 74-80.

15. Зарічна, Т. П. Маркетингове дослідження вітчизняного ринку лікарських засобів, які застосовують у стоматології / Т. П. Зарічна // Український стоматологічний альманах. - 2015. - № 4. - С. 79-83.

16. Компендиум on-line [Електронний ресурс]. - Режим доступу: http://compendium.com.ua

17. Державний реєстр лікарських засобів України [Електронний ресурс]. - Режим доступу: http:// www.drlz.kiev.ua/ 
18. Kovalenko, S. M. Methodological Aspects of Development of Gels for Treating Inflammatory Dental Diseases / S. M. Kovalenko, N. V. Khokhlenkova, J. M. Azarenko // Asian Journal of Pharmaceutics. 2017. - Vol. 11 (1). - P. S129-S135.

19. Соповская, А. В. Актуальные вопросы номенклатуры, состава и технологии стоматологических гелей / А. В. Соповская, А. М. Сампиев, Е. Б. Никифорова // Современные проблемы науки и образования. - 2015. - № 1-1. - Режим доступа: www.science-education.ru/121-18828

20. Заливская, А. В. Анализ основ стоматологических гелей для лечения гингивита / А. В. Заливская, Е. Т. Жилякова // Научный результат. Серия «Медицина и фармация». - 2016. - Т. 2, № 1 (7). - С. 53-58.

21. Кучеренко, В. С. Розробка складу та технології комбінованого гелю для лікування гінгівітів : дис. ... канд. фармац. наук / В. С. Кучеренко. - Харків, 2015. - 176 с.

22. Masliy, Yu. S. Study of biopharmaceutical and adhesive characteristics of a dental gel / Yu. S. Masliy, O. A. Ruban // News of Pharmacy. - 2018. - No. 1 (93). - C. 28-32.

23. Харенко, Е. А. Мукоадгезивные лекарственные формы (обзор) / Е. А. Харенко, Н. И. Ларионова, Н. Б. Демина // Химико-фармацевтический журнал. - 2009. - Т. 43, № 7. - С. 17-24.

24. Фармацевтичні та медико-біологічні аспекти ліків : навч. посіб. для студ., магістрів, аспірантів, викладачів, наук. співробітників та спеціалістів фармації / І. М. Перцев [та ін.]; за ред. I. М. Перцева. - 2-ге вид., перероб. та доп. - Вінниця : Нова Книга, 2007. - 641 с.

\section{References}

1. Borysenko, A. V., Antonenko, M. Yu., Lynovytska, L. V. et al. (2017). Stomatolohichni zakhvoriuvannia: terapevtychna stomatolohiia. Kyiv: Medytsyna, 664.

2. Borysenko, A. V. (2013). Zdorovia suspilstva, 1, 32-37.

3. Melnyk, V. S., Izai, M. E., Duhanchyk, Ya. I. (2016). Molodyi vchenyi, 12.1 (40), 166-169.

4. Kostrigina, E. D., Ziulkina, L. A., Ivanov, P. V. (2017). Izvestiia vysshih uchebnyh zavedenii. Povolzhskii region. Meditsinskie nauki, 3 (43), 118-128.

5. Dmitrieva, L. A. (2014). Parodontologiia. Moscow: GEOTAR-Media, 704.

6. Dychko, E. N., Kovach, I. V., Khotimska, Yu. V., Fedoriak, N. V. (2012). Medychni perspektyvy, 17 (2), 114-116.

7. Herasymenko, S. B., Semenova, A. K., Yeroshenko, H. A., Hasiuk, N. V. (2016). Visnyk problem biolohii $i$ medytsyny, 2, 1 (128), 174-178.

8. Hasiuk, P. A., Kostenko, Ye. Ya., Machohan, V. R., Rosolovska, S. O., Vorobets, A. B. (2016). Almanakh z ortopedychnoi stomatolohii. Ternopil: Navchalna knyha - Bohdan, 352.

9. Trezubov, V. N., Scherbakov, A. S., Mishnev, L. M. (2011). Ortopedicheskaia stomatologiia. Propedevtika i osnovy chastnogo kursa. Sankt-Peterburg: Spetslit, 408.

10. Sokolovska, V. M., Nidzelskyi, M. Ya., Dudchenko, M. O. (2015). Dermatovenerologiia. Kosmetologiia. Seksopatologiia, 3-4, 212-215.

11. Shmanko, V. V., Kotyk, M. I., Mykytiv, M. V. (2015). Visnyk naukovykh doslidzhen, 4, 71-74.

12. Orehova, L. Yu., Kudryavtseva, T. V., Burlakova, Yu. S. (2016). Parodontologiia, 1, 34-39.

13. Davtian, L. L., Voronkina, A. S., Reva, D. V., Kukolevska, O. S. (2015). Farmatsevtychnyi zhurnal, 6, $10-18$.

14. Kozyr, H. R., Vasenda, M. M., Mits, I. R., Kozyr, R. L. (2018). Farmatsevtychnyi chasopys, 1, 74-80.

15. Zarichna, T. P. (2015). Ukrainskyi stomatolohichnyi almanakh, 4, 79-83.

16. Kompendium on-line. Available at: http://compendium.com.ua

17. Derzhavnyi reiestr likarskykh zasobiv Ukrainy. Available at: http://www.drlz.kiev.ua/

18. Kovalenko, S. M., Khokhlenkova, N. V., Azarenko, J. M. (2017). Asian Journal of Pharmaceutics, 11 (1), S129-S135.

19. Sopovskaia, A. V., Sampiev, A. M., Nikiforova, E. B. (2015). Sovremennyie problemy nauki i obrazovaniia, 1-1. Available at: www.science-education.ru/121-18828

20. Zalivskaia, A. V., Zhiliakova, E. T. (2016). Nauchnyi rezultat. Seriia "Meditsina i farmatsiia”, 2, 1 (7), 53-58.

21. Kucherenko, V. S. (2015). Rozrobka skladu ta tekhnolohii kombinovanoho heliu dlia likuvannia hinhivitiv. Candidate's thesis. Kharkiv, 176.

22. Masliy, Yu. S, Ruban, O. A. (2018). News of pharmacy, 1 (93), 28-32.

23. Harenko, E. A., Larionova, N. I., Demina, N. B. (2009). Khimiko-farmatsevticheskii zhurnal, 43 (7), 17-24.

24. Pertsev, I. M. et al. (2007). Farmatsevtychni ta medyko-biolohichni aspekty likiv. Vinnytsia: Nova Knyha, 641 . 
Information about authors:

Maslii Yu. S., Candidate of Pharmacy (Ph. D), associate professor of the Department of Industrial Technology of Drugs,

National University of Pharmacy (http://orcid.org/0000-0002-8968-0262). E-mail: julia.masliy@gmail.com

Ruban O. A., Doctor of Pharmacy (Dr. habil.), professor, Head of the Department of Industrial Technology of Drugs,

National University of Pharmacy (http://orcid.org/0000-0002-2456-8210). E-mail: ruban_elen@ukr.net

Ievtushenko O. M., Doctor of Pharmacy (Dr. habil.), professor of the Department of Pharmaceutical Marketing and Management,

National University of Pharmacy (https://orcid.org/0000-0001-5276-9784). E-mail: evtyshenkolena1@gmail.com

Відомості про авторів:

Maслій Ю. С., кандидат фармацевтичних наук, доцент кафедри заводської технології ліків, Національний

фармацевтичний університет (http://orcid.org/0000-0002-8968-0262). E-mail: julia.masliy@gmail.com

Рубан О. А., доктор фармацевтичних наук, професор, завідувачка кафедри заводської технології ліків,

Національний фармацевтичний університет (http://orcid.org/0000-0002-2456-8210). E-mail: ruban_elen@ukr.net

$\boldsymbol{\epsilon} \boldsymbol{в} у ш е н к о ~ \boldsymbol{~ O . ~ M . , ~ д о к т о р ~ ф а р м а ц е в т и ч н и х ~ н а у к , ~ п р о ф е с о р ~ к а ф е д р и ~ ф а р м а ц е в т и ч н о г о ~ м а р к е т и н г у ~ т а ~ м е н е д ж м е н т у , ~}$

Національний фармацевтичний університет (https://orcid.org/0000-0001-5276-9784).

E-mail: evtyshenkolena1@gmail.com

Сведения об авторах:

Маслий Ю. С., кандидат фармацевтических наук, доцент кафедры заводской технологии лекарств, Национальный фармацевтический университет (http://orcid.org/0000-0002-8968-0262). E-mail: julia.masliy@gmail.com

$\boldsymbol{P} \boldsymbol{y} \boldsymbol{\alpha} \boldsymbol{\boldsymbol { H }} \boldsymbol{E}$. A., доктор фармацевтических наук, профессор, заведующая кафедрой заводской технологии лекарств,

Национальный фармацевтический университет (http://orcid.org/0000-0002-2456-8210). E-mail: ruban_elen@ukr.net

$\boldsymbol{E} \boldsymbol{в} \boldsymbol{л ш е н к о ~} \boldsymbol{E}$. $\boldsymbol{H}$., доктор фармацевтических наук, профессор кафедры фармацевтического маркетинга

и менеджмента, Национальный фармацевтический университет (https://orcid.org/0000-0001-5276-9784).

E-mail: evtyshenkolena1@gmail.com 